\author{
Леся Височан, \\ кандидат педагогічних наук, \\ доцент кафедри фахових методик \\ і технологій початкової освіти, \\ ДВНЗ «Прикарпатський національний \\ університет імені Василя Стефаника» \\ (м. Івано-Франківськ, Україна)
}

\section{Lesya Vysochan,} Ph. D.(Pedagogy), Candidate of Pedagogical sciences, associate professor Department of Professional and Methods and Technologies of Elementary Education, Vasyl Stefanyk Precarpathian National University (Ivano-Frankivsk, Ukraine) lesjavusochan@gmail.com ORCID ID 0000-0002-4951-0074

\title{
ФОРМУВАННЯ ПРИРОДНИЧО-НАУКОВОЇ КОМПЕТЕНТНОСТІ МАЙБУТНІХ УЧИТЕЛІВ ПОЧАТКОВОЇ ШКОЛИ: ДЕФІНІТИВНО-НАУКОВИЙ ДИСКУРС
}

Анотація. У статті представлений аналіз науково-дефінітивного дискурсу проблеми формування природничонаукової компетентності майбутніх учителів початкової школи як важливого теоретико-методологічне підґрунтя їхнього професійного становлення. Виходячи з аналізу репрезентативних досліджень українських і зарубіжних учених та базових нормативних освітніх документів синтезована рецепція компетентнісного підходу в професійно-педагогічній освіті як концептуального науково-теоретичного підгрунтя удосконалення її змісту та орієнтованості на підвищення рівня знань, навичок, досвіду, обізнаності, необхідних для продуктивної діяльності, фахового прийняття рішень, ефективної комунікації в різних сферах і галузях суспільного і професійного життя.

Запропоновано визначення природничо-наукової компетентності майбутнього вчителя початкової як сукупності актуалізованих якостей і властивостей та інтелектуальну, особистісно обумовлену соціально-професійну характеристику, що ґрунтується на засвоєних знаннях, уміннях, навичках, набутому практичному досвіді, ціннісних орієнтаціях, моральносвітоглядних уявленнях, спроможності самостійно організовувати і здійснювати науково-дослідну діяльність, готовності самостійно розв'язувати професійні завдання, здатності до творчого мислення, саморозвитку, самовдосконалення. 3'ясовано суть предметної природничо-наукової компетентності майбутнього фахівця

Ключові слова: природничо-наукова компетентність, компетенція, предметна компетентність, майбутній учитель, початкова школа.

\section{FORMATION OF NATURAL SCIENTIFIC COMPETENCE OF FUTURE PRIMARY SCHOOL TEACHERS: DEFINITIVE SCIENTIFIC DISCOURSE}

\begin{abstract}
The article reveals the substantive and methodological features and productive experience of using educational and game technologies in the formation of natural science competence of future primary school teachers. The scientific approaches to the interpretation of game activity as a kind of pedagogical technologies are analyzed. The structure, content, methods, and other aspects of the implementation of initial game technologies developed in the psychological and pedagogical literature are revealed. It is substantiated that the use of educational and game technologies in natural science training of future primary school teachers provides for the purposeful application of a set of methods, techniques and tools for organizing the pedagogical process, focused on solving specific cognitive tasks, focused on solving specific educational and cognitive tasks. The productive practical experience of using educational and game technologies in natural science is presentedtraining of future teachers (natural quest, biodesign, etc.) and primary school students. Keywords: natural science competence, educational technologies, educational and game technologies, future teacher, primary school.
\end{abstract}

\section{ВСТУП}

Постановка проблеми. За сучасних умов інтеграції України в європейський освітній простір, складних процесів реформування її національної системи освіти, викликів глобалізації та ринку праці компетентнісний підхід стає однією з ключових парадигм професійної підготовки майбутніх фахівців та методологічних інструментів вивчення цієї проблеми. 3 такої позиції, що інтегрує освітньо-педагогічний та науково-теоретичний аспекти професійного становлення майбутніх учителів початкової школи, підходимо до з'ясування науково- 
дефінітивного дискурсу формування їхньої науково-природничої компетентності як теоретико-методологічного підґрунтя практичного розв'язання цієї проблеми.

Аналіз наукових досліджень і публікацій. З'ясуванню сутності термінів «компетентнісний підхід», «компетентність», «компетенція» та пов'язаних з ними дефініцій присвячено значний пласт наукової літератури (О. Андрєєв, І. Андрусенко, А. Бальоха, І. Бех, О. Біда, Г. Білецька, Н. Біліченко, С. Бондар, Н. Борисенко, О. Борисюк, О. Войтович, І. Зімняя, В. Лунячек, О. Овчарук, Н. Побірченко, А. Хуторской, Г. Семашкіна та ін.). Це знімає потребу деталізації їхніх численних тлумачень та уможливлює безпосередньо зосередитися на аналізі наукового дискурсу щодо означеної в назві статті проблеми.

\section{МЕТА І ЗАВДАННЯ ДОСЛІДЖЕННЯ}

Мета і завдання статі полягають у здійсненні синтезованого аналізу дефініцій, необхідних для предметного осмислення проблеми формування природничо-наукової компетентності майбутніх учителів початкової школи, як теоретико-методологічне підґрунтя практичного розв'язання цієї проблеми в освітньому процесу закладу вищої освіти.

\section{РЕЗУЛЬТАТИ ДОСЛІДЖЕННЯ}

Репрезентативні науково-теоретичні напрацювання українських і зарубіжних учених відображають різноманіття тлумачень і підходів до вивчення феноменів компетентнісного підходу і компетентності загалом та в проекції професійної підготовки майбутніх учителів початкової школи зокрема (Андрусенко І.В., 2013; Бех І.Д., 2012; Біліченко Н.М., 2016; Борисенко Н.М., Семашкіна Г.М., 2014; Борисюк О.М., 2013; Компетентнісний, 2004; Компетентності, 2018; Кононенко Н., 2013; Лунячек В., 2013; Савченко О.П., 2010; Хуторской А., 2004; Шишов С., 2002 та ін.). Узагальнювальний аналіз цього наукового доробку та нормативно-правових документів (Державний, 2018; Компетентності, 2018; Концепція, 2016; Методичні, 2016; Методичні, 2017 та ін.) свідчить, що визначення істотних ознак феномену компетентності фокусується на компонентах, пов'язаних із формуванням знань, умінь, навичок, ставлень, здібностей, мотивацій та способів діяльності особистості.

Важливе значення для нашого дослідження має рефлексія компетентнісного підходу в професійно-педагогічній освіті як концептуального науково-теоретичного підґрунтя вдосконалення її змісту та орієнтованості на підвищення рівня знань, навичок, досвіду, обізнаності, необхідних для продуктивної діяльності, фахового ухвалення рішень, ефективної комунікації в різних сферах суспільного і професійного життя. Продуктивним і перспективним $€$ трактування компетентнісного підходу як методу моделювання результатів професійної освіти і навчання, що увиразнено у вигляді норм і показників якості підготовки кваліфікованого фахівця.

Синтезуючи ідеї і концепти наукового дискурсу, заявленого в означених та інших студіях, маємо підстави говорити про певний консенсус у трактуваннях компетентності як «інтегрованої характеристики» здобувача освіти. Визріває розуміння того, що компетентнісний підхід не суперечить традиційному «знаннєвому» підходу, тож ці два феномени є важливими взаємоінтегрованими компонентами професійно-педагогічної освіти, які органічно доповнюють один одного та розширюють зміст особистісно орієнтованого освітнього процесу. Кристалізується усвідомлення, що «педагогіка знань» і «педагогіка розвитку» забезпечують формування «компетентності вищого порядку», тому педагогіка має запропонувати модель навчального процесу, що одночасно розв'язує два задання: засвоєння знань та розвиває здатності і здібності мислення.

На початку XXI ст. в європейському та українському науково-освітньому просторі компетентнісний підхід перетворився на універсальний методологічний інструмент характеристики різних компонентів системи вищої освіти, її цілей, змісту, методів, форм, засобів, механізмів реалізації, визначення результатів тощо. Таке його розуміння відповідає європейській освітньо-науковій парадигмі, згідно з якою компетентнісний підхід (Competence-based approach) орієнтований на визначення результатів навчання та передбачає їхній опис у термінах компетентностей. Він розглядається як ключовий метод реалізації цілей Болонського процесу, фокусуючи на їхній студентоцентровій спрямованості (Вступне, с. 15-35; Національний, 2014).

У сучасному вітчизняному науковому дискурсі побутує розгляд компетенції як складника компетентності, що відображає рівень знань, умінь, навичок, досвіду, сформованих здібностей і ціннісних установок, необхідних для ефективного виконання професійної діяльності. Таким чином, породжуючи вміння і дії, компетенції сприяють встановленню зв'язків між знаннями і ситуацією, що забезпечує реалізацію компетентнісного підходу як дієвого і ефективного методу розв'язання освітніх і соціальних проблем.

Означена наукова позиція, безумовно, має право на існування, однак портібно враховувати, що в репрезентативних зарубіжних наративах на кшталт «Проект ТЮНІНГ - гармонізація освітніх структур у Європі. Внесок університетів у Болонський процес» (Проєкт) та розроблених на їхній основі нормативно-правових документів України (Національний, 2014), як і в освітній практиці, категорії «компетентність» і «компетенція» здебільшого вживаються як синонімічні.

Така позиція відповідає положенням міжнародних освітніх документів, у яких категорії «компетентність», «компетентності», «компетенції» (Competence, competency / competences, competencies) визначаються у спільному ракурсі як мінлива і динамічна або статична, усталена комбінація знань, умінь, навичок та способів мислення, професійних і громадянських якостей, морально-етичних цінностей. За такого підходу компетентності розглядаються передусім як результат навчання на певному рівні вищої освіти. Вони лежать в основі кваліфікації випускника та визначають його готовність і здатність успішно здійснювати навчальну й подальшу професійну діяльність

Таку позицію можна (до певної міри) вважати нормативною, адже в Законі України «Про вищу освіту» (2014 р.) компетентність визначається як динамічна комбінація знань, умінь і практичних навичок, способів мислення, професійних, 
світоглядних і громадянських якостей, морально-етичних цінностей, що визначають здатність особи успішно здійснювати професійну і подальшу навчальну діяльність та є результатом навчання на певному рівні вищої освіти (ст. 1, п. 13).

Для вивчення проблеми формування професійної компетентності працівників галузі педагогічної освіти загалом та природничо-наукової компетентності майбутніх учителів початкової школи зокрема важливе науково-теоретичне значення мають напрацьовані у 2011 - 2018 рр. Міністерством освіти України спільно з АПН України та Інститутом інноваційних технологій і змісту освіти методичні рекомендації з розроблення складників галузевих стандартів вищої освіти на основі компетентнісного підходу (Методичні, 2016; Методичні, 2017 та ін.). У цих документах компетентність розглядається як інтегрована характеристика якостей особистості та результат підготовки випускника ЗВО до виконання діяльності в певних професійних і соціально-особистісних предметних галузях, що відображають і формалізують певний обсяг і рівень знань, досвіду в конкретному виді професійної діяльності.

Як бачимо, з одного боку, компетенції включають теоретичні знання та розуміння можливостей практичного застосування знань за конкретних ситуацій. 3 іншого боку, вони фокусують на предметній галузі, у якій особа фахівця (у нашому випадку майбутнього вчителя початкової школи) має бути добре обізнана та виявляти готовність і здатність до виконання професійної діяльності (Методичні, 2016; Методичні, 2017).

у новому Державному стандарті початкової освіти (2018) компетентність визначається як набута в процесі навчання, інтегрована здатність особистості, яка складається зі знань, досвіду, цінностей і ставлення, що можуть цілісно реалізовуватися на практиці (Державний, 2018). Таке тлумачення суголосне з положеннями «Рекомендацій Європейського Парламенту та Ради Європи щодо формування ключових компетентностей освіти впродовж життя» (2006) та Концепцією Нової української школи, у якій, зокрема, зазначається, що компетентність - це динамічна комбінація знань, способів мислення, поглядів, цінностей, навичок, умінь, інших особистих якостей, які визначають здатність особи успішно провадити професійну та/або подальшу навчальну діяльність (Концепція, 2016).

Розглядаючи компетентнісний підхід у площині професійно-педагогічної підготовки майбутніх учителів, науковці акцентують на тому, що його впровадження скеровує управління навчально-пізнавальним процесом на співпрацю зі студентами, діалогічне навчання та самовдосконалення тих, хто вчить, і тих, хто навчається (Компетентнісний, 2004). Зі свого боку О. Савченко акцентує на компетентності як інтегральній якості особистості, яка виявляється в загальній здатності і готовності діяти; вона базується на знаннях і досвіді, набутих у процесі навчання і соціалізації, та орієнтованості на самостійну, успішну участь у професійно-педагогічній діяльності (Савченко О.П, 2010).

Доцільним і продуктивним для нашого дослідження є трактування компетентності як співвідношення між знаннями і практичними діями, що проявляються в здатності до діяльності в реальних життєвих ситуаціях на основі набутих знань. Таким чином, воно розглядається у вузькому значенні як можливість установлення взаємозв'язків між знаннями та навчальними, професійними і життєвими ситуаціями та в широкому - як здібність знайти і виявити процедури, тобто знання і дії, які придатні для розв'язання різних проблем (Шишов С., 2002, с. 20).

Як інтегральна якість особистості майбутнього вчителя початкової школи природничо-наукова компетентність включає вузькоспеціальні (профільні) знання, навички, способи мислення і розуміння відповідальності за свої дії; особистісне ставлення до предмета науково-дослідницької діяльності та реально сформовані особистісні якості й набутий досвід її здійснення. За такого підходу потрібно створювати умови й середовище для практичних дій суб'єктів навчання, завдяки яких ключові компетенції могли б формуватися, реалізуватися та вдосконалюватися.

З огляду на означені нормативні освітні документи та наукові студії, природничо-наукову компетентність майбутніх учителів початкової школи визначаємо як сукупність актуалізованих якостей і властивостей та інтелектуальну, особистісно зумовлену соціально-професійну характеристику, що ґрунтується на засвоєних знаннях, уміннях, навичках, набутому практичному досвіді, ціннісних орієнтаціях, морально-світоглядних уявленнях, спроможності самостійно організовувати і здійснювати науково-дослідницьку діяльність, готовності самостійно розв'язувати професійні завдання, здатності до творчого мислення, саморозвитку, самовдосконалення.

Як інтегральна якість особистості майбутнього вчителя початкової школи природничо-наукова компетентність включає і синтезує вузькоспеціальні (профільні) знання, навички, способи мислення і розуміння відповідальності за свої дії; особистісне ставлення до предмета науково-дослідницької діяльності та реально сформовані особистісні якості й набутий досвід її здійснення. За такого підходу слід створювати умови й середовище для практичних дій суб'єктів навчання, завдяки яким ключові компетенції могли б успішно формуватися, реалізуватися та вдосконалюватися.

Для нашого дослідження особливо важливим $€$ тлумачення предметної природознавчої компетентності в Державному стандарті початкової загальної освіти як «особистісного утворення, що характеризує здатність учня розв'язувати доступні соціально і особистісно значущі практичні та пізнавальні проблемні задачі, пов'язані 3 реальними об'єктами природи у сфері відносин «людина - природа» (Державний, 2018, с. 2),

Зважаючи на це, предметну (спеціальну, профільну) природничо-наукову компетентність майбутнього вчителя початкових класів розглядаємо як освоєний у процесі ознайомлення з довкіллям досвід діяльності (сукупність знань, умінь, досвіду, особистісних якостей, професійних характеристик), який, з одного боку, формується на основі сукупності уявлень, знань, умінь, ставлень та оцінних суджень до предметів і явищ природного оточення, а з іншого боку, виявляється і реалізується в процесі науково-аналітичної і дослідницької роботи та майбутньої різнобічної педагогічної діяльності.

Такий підхід відповідає сучасній концепції природознавства, яка проголошує пріоритети взаємодії людини і природи в сенсі єдності, що ґрунтується на ставленні до екосередовища як універсальної, унікальної цінності й чинника, формуванні науково-природничої картини світу. Вона базується на універсальних законах природи й 
розвитку соціуму та передбачає формування наукового гуманістичного світогляду, що визначає місце і діяльність людини в природі й сучасному світі.

\section{ВИСНОВКИ ТА ПЕРСПЕКТИВИ ПОДАЛЬШИХ ДОСЛІДЖЕНЬ}

Отже, проблема формування природничо-наукової компетентності є однією зі стрижневих у вивчені та розробці й реалізації теорії і практики професійної підготовки майбутніх учителів початкової школи. Вона наскрізь пронизує освітній процес у педагогічних закладах вищої освіти, адже апріорі впливає на визначення його мети, завдань, змісту, технологій, методів, форм і засобів упровадження та визначення готовності майбутнього фахівця до виконання професійних обов'язків.

Предметом подальшого наукового дослідження має стати проблема формування предметної природознавчої компетентності молодших школярів як базового орієнтиру природничо-наукової підготовки майбутнього вчителя.

\section{СПИСОК ВИКОРИСТАНИХ ДЖЕРЕЛ}

Андрусенко І. В. (2013). Формування екологічних умінь як складник природознавчої компетентності. Початкова школа. $12.13-16$. Бех І. Д. (2012). Компетентнісний підхід у сучасній освіті. URL: http://www.ipv.org.ua/component/8-beh/56-2012-09-04-22-32-01.html. Біліченко H. М. (2016). Формування природознавчої компетентності молодших школярів. URL: www.school86.com.ua ,

Борисенко Н. М., Семашкіна Г. М. (2014). Пропедевтика формування природознавчої компетентності молодших школярів у процесі фенологічних спостережень. Педагогічні науки. Херсон. 65. 80-85.

Борисюк О. М. (2013) Поняття «компетентність» в сучасній психолого-педагогічній літературі. Проблеми екстремальної та кризової психології. 14. 43-51.

Вступне слово до проекту TЮHIHГ - гармонізація освітніх структур у Європі. Внесок університетів у Болонський процес. URL: irbisnbuv.gov.ua > cgiirbis_64.

Державний (2018) стандарт початкової освіти. URL: https://www.kmu.gov.ua/ua/npas/pro-zatverdzhennya. pochatkovoyi-osviti

Лунячек В. Компетентнісний підхід як методологія професійної підготовки у вищій школі (2013). URL: http://www.kbuapa p/2013-1/ doc/4/01.pdf.

Компетентнісний підхід у сучасній освіті: світовий досвід та українські перспективи (2004). Монографія. О.В. Овчарук та ін. Київ: K.I.C. 345 C.

Компетентності вчителя початкової школи, необхідні для навчання учнів перших класів у 2018/2019 і $2019 / 2020$ навчальних роках. URL: tyachiv.osv.org.ua > kompete.

Кононенко Н. (2013). Формування природничо-наукової компетентності майбутніх учителів початкової школи. Біологія і хімія в сучасній школі. 4. 42-45.

Концепція Нової української школи (2016): http://mon.gov.ua/activity/ ua-sch-

Методичні рекомендації щодо розроблення стандартів вищої освіти (2017). Затверджено. Наказ Міністерства освіти і науки України від 01 червня 2017 № 600. URL: https://mon.gov.ua/storage/...osvita/rekomendatsii-1648.pdf.

Методичні рекомендації щодо розроблення стандартів вищої освіти (2016). Схвалено рішенням колегії Міністерства освіти і науки України протокол від 28.04.2016 № 5/6-4. URL: https://osvita.ua/doc/files/news/515/51506/

Національний освітній глосарій: вища освіта. (2014). Київ: «Плеяди».

Савченко О.П. Компетентнісний підхід у сучасній вищій школі (2010). Е-журнал «Педагогічна наука: історія, теорія, практика, тенденції розвитку». 3. URL: http://intellect-invest.org.ua/pedagog_editions_e-.

Хуторской А. (2003). Ключевые компетенции как компонент личностно- ориентированной парадигмы образования. Народное образование. 2. 58-64.

Шишов С. (2002) Понятие компетентности в контексте качества образования. Дайджест педагогических идей и технологий. 3. $20-21$.

\section{REFERENCES}

Andrusenko, I. V. (2013). Formuvannia ekolohichnykh umin yak skladnyk pryrodoznavchoi kompetentnosti [Formation of ecological skills as a component of natural science competence]. Pochatkova shkola - Elementary School, 12, 13-16.

Bekh, I. D. (2012). Kompetentnisnyi pidkhid u suchasnii osviti [Competent approach in modern education]. URL: http://www.ipv.org.ua/component/8beh/56-2012-09-04-22-32-01.html.

Bilichenko, N. M. (2016). Formuvannia pryrodoznavchoi kompetentnosti molodshykh shkoliariv [Formation of natural science competence of young schoolch]. URL: www.school86.com.ua >

Borysenko, N. M., \& Semashkina, H. M. (2014). Propedevtyka formuvannia pryrodoznavchoi kompetentnosti molodshykh shkoliariv u protsesi fenolohichnykh sposterezhen [Propaedeutics of formation of natural science competence of junior schoolchildren in the process of phenological observations]. Pedahohichni nauky - Pedagogical sciences. Kherson, 65, 80-85.

Borysiuk, O. M. (2013) Poniattia «kompetentnist» v suchasnii psykholoho-pedahohichnii literaturi [The concept of "competence" in modern psychological and pedagogical literature]. Problemy ekstremalnoi ta kryzovoi psykholohii - Problems of extreme and crisis psychology,14, 43-51.

Derzhavnyi standart pochatkovoi osvity [State standard of primary education] (2018). URL: https://www.kmu.gov.ua/ua/npas/pro-zatverdzhennya. pochatkovoyi-osviti

Luniachek, V. Kompetentnisnyi pidkhid yak metodolohiia profesiinoi pidhotovky u vyshchii shkoli [Competence approach as a methodology of professional training in higher education.] (2013). URL: http://www.kbuapa p/2013-1/doc/4/01.pdf.

Khutorskoi, A. (2003). Kliuchevye kompetentsyy kak komponent lychnostno- oryentyrovannoi paradyhmy obrazovanyia [Key competencies as a component of the personality-oriented paradigm of education]. Narodnoe obrazovanye - Public education, 2, 58-64.

Kompetentnisnyi pidkhid u suchasnii osviti: svitovyi dosvid ta ukrainski perspektyvy [Competence approach in modern education: world experience and Ukrainian perspectives] (2004). Monohrafiia. O.V. Ovcharuk ta in. Kyiv: K.I.S.

Kompetentnosti vchytelia pochatkovoi shkoly, neobkhidni dlia navchannia uchniv pershykh klasiv u 2018/2019 i 2019/2020 navchalnykh rokakh [Competences of primary school teachers required for teaching first grade students in 2018/2019 and 2019/2020 academic years].URL: tyachiv.osv.org.ua > kompete. 
Kononenko, N. (2013). Formuvannia pryrodnycho-naukovoi kompetentnosti maibutnikh uchyteliv pochatkovoi shkoly [Formation of natural science competence of future primary school teachers]. Biolohiia i khimiia v suchasnii shkoli - Biology and chemistry in the modern school, 4,42-45. Kontseptsiia Novoi ukrainskoi shkoly [The concept of the New Ukrainian School] (2016). URL: http://mon.gov.ua/activity/ ua-sch-

Metodychni rekomendatsii shchodo rozroblennia standartiv vyshchoi osvity [Guidelines for the development of standards of higher education] (2017). Zatverdzheno. Nakaz Ministerstva osvity i nauky Ukrainy vid 01 chervnia 2017 № 600. URL: https://mon.gov.ua/storage/...osvita/ rekomendatsii-1648.pdf.

Metodychni rekomendatsii shchodo rozroblennia standartiv vyshchoi osvity [Guidelines for the development of standards of higher education] (2016). Skhvaleno rishenniam kolehii Ministerstva osvity i nauky Ukrainy protokol vid 28.04.2016 № 5/6-4. URL: https://osvita.ua/doc/files/ news/515/51506/

Natsionalnyi osvitnii hlosarii: vyshcha osvita [National Education Glossary: Higher Education]. (2014). Kyiv: Pleiady.

Savchenko, O. P. (2010). Kompetentnisnyi pidkhid u suchasnii vyshchii shkoli [Competence approach in modern higher education]. E-zhurnal «Pedahohichna nauka: istoriia, teoriia, praktyka, tendentsii rozvytku» - Pedagogical science: history, theory, practice, development trends, 3. URL: http://intellect-invest.org.ua/pedagog_editions e-.

Shyshov, S. (2002) Poniatye kompetentnosty v kontekste kachestva obrazovanyia [The concept of competence in the context of the quality of education]. Daidzhest pedahohycheskykh ydei y tekhnolohyi - Digest of pedagogical ideas and technologies, 3, 20-21.

Vstupne slovo do proektu TluNINH - harmonizatsiia osvitnikh struktur u Yevropi. Vnesok universytetiv u Bolonskyi protses [Introductory word to the TUNING project - harmonization of educational structures in Europe. The contribution of universities to the Bologna Process]. URL: irbisnbuv.gov.ua > cgiirbis_64.

Статтю подано до редколегії 16.07 .2020 р.

Рекомендовано до друку

04.08 .2020 p. 